\title{
TINJAUAN YURIDIS PEMIDANAAN TERHADAP PELAKU TINDAK PIDANA PENJARAHAN
}

\author{
Komang Gede Reska Joanykernia Pradila, Anak Agung Sagung Laksmi Dewi, I Made Minggu Widyantara \\ Fakultas Hukum, Universitas Warmadewa, Denpasar-Bali, Indonesia \\ reskajoanykerniap@gmail.com, laksmiidewi29@gmail.com, mademinggu21@gmail.com
}

\begin{abstract}
Abstrak
Perkembangan zaman di Indonesia dalam berbagai aspek yang sangat pesat membuat pola tingkah laku masyarakat Indonesia beragam. Dilihat dari perspektif hukum, ada perilaku yang sesuai dengan norma yang berlaku dan ada pula perilaku yang menyimpang dari norma yang berlaku. Salah satu perbuatan yang menyimpang adalah tindak pidana penjarahan. Penjarahan adalah kejahatan pencurian yang dilakukan dengan cara mengambil barang milik orang lain secara paksa yang dilakukan saat sedang terjadi bencana alam, kerusuhan, kecelakaan pesawat terbang dan kecelakaan kereta api. Tujuan penelitian ini yaitu untuk menganalisa sanksi pidana terhadap pelaku tindak pidana penjarahan dan pertimbangan hakim dalam menjatuhkan pidana terhadap pelaku tindak pidana penjarahan. Penelitian ini menerapka metode penelitian normatif. Adapun bahan hukum yang digunakan yaitu bahan hukum primer, sekunder dan tersier dengan teknik inventarisasi atau penelusuran bahan hukum yang bersangkutan kemudian diklasifikasikan atau dikelompokkan dan didokumentasikan, dicatat, dikutip, diringkas, ditinjau sesuai kebutuhan dengan menggunakan pendekatan kualitatif yang kemudian dianalisis secara sistematis. Hasil penelitian mengungkapkan bahwa Orang yang melakukan tindak pidana penjarahan akan dikenakan sanksi pidana sesuai pasal 363 KUHP ayat (1) ke-2 dengan mempertimbangkan pasal 10 KUHP dan wajib halnya bagi pelaku untuk mempertanggungjawabkan perbuatannya.
\end{abstract}

Kata Kunci: Penjarahan, Sanksi Pidana, Tindak Pidana

\begin{abstract}
The rapid development of the times in Indonesia in various aspects has made the behavior patterns of the Indonesian people diverse. Seen from a legal perspective, there is behavior that is in accordance with applicable norms and there is also behavior that deviates from applicable norms. One of the deviant acts is the crime of looting. Looting is the crime of theft which is carried out by forcibly taking other people's belongings which is carried out during natural disasters, riots, airplane accidents and train accidents. The purpose of this study is to analyze the criminal sanctions against the perpetrators of the crime of looting and the judge's considerations in imposing a sentence on the perpetrators of the crime of looting. This research applies normative research methods. The legal materials used are primary, secondary and tertiary legal materials with the technique of inventorying or tracing the relevant legal materials then classified or grouped and documented, recorded, quoted, summarized, reviewed as needed using a qualitative approach which is then analyzed systematically. The results of the study reveal that people who commit the crime of looting will be subject to criminal sanctions according to article 363 of the 2nd KUHP paragraph (1) by considering article 10 of the Criminal Code and it is obligatory for the perpetrators to be held accountable for their actions.
\end{abstract}

Keywords: Looting, Criminal Sanctions, Crime

\section{PENDAHULUAN}

Dengan kemajuan ilmu pengetahuan, budaya, dan teknologi, perilaku manusia dalam kehidupan sosial menjadi semakin beragam. Dari segi hukum, perilaku ini dapat dibedakan menjadi perilaku berdasarkan norma yang berlaku dan perilaku yang berbeda dengan norma saat ini. Pelanggaran terhadap regulasi yang ada di Indonesia saat ini akan merusak ketentraman dan ketertiban kehidupan sosial.

Setiap individu yang hidup di kehidupan bermasyarakat akan diatur segala tingkah lakunya dalam sebuah aturan hukum, baik hukum adat yang ada di daerahnya maupun hukum positif yang diciptakan oleh pemerintah Indonesia. Oleh karena itu, hukum tidak terlepas dari pengaruh timbal balik dari semua aspek yang ada, yang merupakan patokan hukum yang dapat menciptakan 
ketertiban dalam kehidupan bermasyarakat. Namun nyatanya, masih banyak orang yang melakukan pelanggaran hukum baik disengaja maupun tidak disengaja.

Salah satu prinsip pembangunan nasional bertumpu pada penghargaan terhadap sikap aparat penegak hukum terhadap penegakan hukum, keadilan, dan perlindungan martabat manusia. Pada saat yang bersamaan, arah kebijakan tersebut mengatur ketertiban dan kepastian hukum dalam melindungi setiap orang, yang tidak terlepas dari keterkaitannya dengan kebudayaan Indonesia berdasarkan Pancasila.

Kejahatan terjadi di setiap ruang, tempat, waktu dan negara. Kejahatan merupakan fakta yang terjadi di kehidupan manusia. Satu-satunya cara yang bisa kita lakukan adalah melakukan upaya yang dapat mencegah dan mengurangi kejahatan sosial. Kejahatan dan hukuman sangat erat kaitannya, karena orang yang melakukan kejahatan harus dikirim ke pengadilan dan dijatuhi hukuman yang sama. Para pelaku tindak pidana kemudian hidup di belakang tembok penjara yang berbeda baginya. Mereka berkumpul bersama dengan penjahat yang berbeda, begitu pula bahasa, stratifikasi sosial, dan berbagai latar belakang.

Setiap perbuatan rakyat Indonesia tentu diatur segala perbuatannya dalam suatu UndangUndang. Sesuai dengan pasal 28J ayat (2) Kemudian setiap orang berkewajiban untuk mematuhi batasan yang ditetapkan oleh hukum, yang satu- satunya tujuannya adalah untuk memastikan bahwa hak dan kebebasan orang lain diakui dan dihormati, dan untuk memenuhi persyaratan keadilan dalam masyarakat di bawah pertimbangan demokrasi, moralitas, nilai-nilai agama, keamanan dan ketertiban umum. Ada beberapa jenis tindak pencurian, salah satunya adalah pencurian dengan pemberatan. Kejahatan pencurian dengan pemberatan menimbulkan kerugian dan penderitaan yang dialami oleh korban kejahatan. Tindak pidana ini sudah sangat jelas diatur dalam pasal 363 Kitab Undang-Undang Hukum Pidana. Penjarahan termasuk ke dalam kategori tindak pidana pencurian dengan pemberatan. Dalam proses beracara di pengadilan, kasus pencurian dengan pemberatan khususnya penjarahan penjarahan diatur dalam Kitab Undang-Undang Hukum Acara pidana sebagai bentuk hukum materiil. Begitu pentingnya hukum acara, diharapkan dapat membuat pengadilan menjadi wibawa sehingga dihormati masyarakat pencari keadilan. Tindak Pidana Penjarahan dan/atau Pencurian hanya disebutkan dalam Pasal 78 tentang Penadahan bukan Tindak Pidana Pencurian (Susan, 2019). Faucon (2010) setidaknya ada 3 peristiwa yang dapat menyebabkan terjadinya penjarahan. Pertama, peperangan. Kedua, kerusuhan masyarakat. Ketiga, bencana alam.

Kalaupun ada regulasi yang mengatur kejahatan yang terjadi di masyarakat, aturan tersebut sepertinya tidak menjamin perlindungan kepentingan masyarakat luas. Berkenaan dengan aparat penegak hukum, saat ini masih lambat dalam menyelesaikan proses penanganan perkara. Masih ada yang bertahun-tahun baru diperoleh putusan final atas suatu perkara bahkan pada tahap penyidikan masih ada yang hampir setahun. Berbagai hambatan masih dialami. Salah satu hambatan adalah kurangnya penerapan hukum. Sudah sangat jelas hal ini akan memperlambat proses penanganan perkara. Dari segi orang yang dapat terkait dengan penanganan perkara khususnya yang berkepentingan merupakan suatu beban mental dan kekurang tenteraman batin. Dengan demikian, akan menurunkan produktivitas dan profesional aparat penegak hukum. Hal yang demikian dapat dicegah dengan meningkatkan pengetahuan penerapan hukum bagi aparat penegak hukum sehingga Penuntut Umum yang menuntut bebas atau terdakwa yang dibebaskan Pengadilan Negeri/Pengadilan Tinggi/Mahkamah Agung dapat berkurang untuk mengurangi ketidakstabilan batin tersangka/terdakwa.

Terdapat penelitian terdahulu terkait penjarahan yang relevan dengan penelitian ini, menurut Sidiq (2019) pencurian atau penjarahan yang terjadi pada saat bencana alam termasuk kedalam pencurian dengan pemberatan. Sebagaimana diatur dalam pasal 363 ayat (1) Kitab Undang-undang Hukum Pidana (KUHP). Penelitian dari Hasan (2021) upaya hukum yang ditempuh oleh pihak kepolisian dalam menanggulangi tindak pidana pencurian atau penjarahan yang dilakukan pada saat terjadinya bencana alam ada dua yaitu; upaya preventif yang berupa semua urusan atau kebijaksanaan yang diambil sebelum terjadinya suatu kejadian dalam rangka mencegah terjadinya tindak pidana pencurian dan upaya represif yaitu tindakan yang diambil sesudah timbulnya kejahatan yang dilakukan oleh seseorang dengan tujuan agar kejahatan atau tindakan pencurian itu jangan sampai terjadi lagi. Adapun penelitian dari Nainggolan (2013) mengenai penjarahan lahan di Indonesia, baginya dalam menghentikan laju konversi lahan harus dilakukan melalui implementasi secara konsisten UU No. 41 Tahun 2009 tentang Perlindungan Lahan Pertanian Berkelanjutan. UU yang 
bertujuan melindungi memberdayakan petani itu harus didukung implementasinya, agar upaya baru memperluas lahan pertanian dapat dilakukan.

Berdasarkan pada uraian diatas, tujuan penelitian ini untuk menganalisa sanksi pidana terhadap pelaku tindak pidana penjarahan dan pertimbangan hakim dalam menjatuhkan pidana terhadap pelaku tindak pidana penjarahan.

\section{METODE PENELITIAN}

Penelitian yang penulis gunakan adalah penelitian hukum normatif (Hartono, 1994) yaitu penelitian dilakukan dengan menganalisis peraturan perundang-undangan yang berlaku. Mengenai sumber bahan hukum yang digunakan terbagi atas bahan hukum utama yang merupakan bahan hukum utama dan menjadi dasar dalam penelitian ini. Bahan Hukum sekunder adalah adalah bahan hukum yang digunakan untuk menunjang atau membantu dalam memberikan pemahaman-pemahaman dan gambaran-gambaran serta teori-teori hukum yang digunakan untuk mengulas dan memecahkan persoalan-persoalan yang akan di teliti di dalam penelitian ini. Bahan Hukum Tersier adalah bahan hukum yang memberikan pedoman dan interpretasi bagi bahan hukum tingkat pertama dan kedua. Untuk memperoleh bahan hukum primer, sekunder dan tersier, maka teknik inventarisasi atau penelusuran bahan hukum yang bersangkutan kemudian diklasifikasikan atau dikelompokkan dan didokumentasikan, dicatat, dikutip, diringkas, ditinjau sesuai kebutuhan dengan menggunakan pendekatan kualitatif. Setelah bahan hukum primer dan sekunder terkumpul, ini akan diolah dan dianalisis menggunakan metode penanganan bahan hukum yang sistematis.

\section{HASIL DAN PEMBAHASAN}

\section{Sanksi Pidana Terhadap Pelaku Tindak Pidana Penjarahan}

Kejahatan disebut juga kejahatan atau perilaku yang dapat dihukum, atau kejahatan adalah perilaku yang melanggar atau melanggar hukum yang dilakukan oleh orang yang bertanggung jawab (Soesilo, 1972). Istilah "acara pidana" merupakan terjemahan dari "strafbaar feit". Dalam KUHAP tidak dijelaskan arti sebenarnya dari acara pidana itu sendiri (Prasetyo, 2010). Tujuan pemberian sanksi adalah untuk melindungi kepentingan masyarakat secara kolektif, dari tindakan yang mengancam atau bahkan merugikan masyarakat, terlepas dari apakah tindakan tersebut berasal dari individu atau kelompok. Berbagai kepentingan sosial termasuk kedamaian, ketenangan dan ketertiban dalam kehidupan masyarakat. Sebagai sumber utama atau sumber utama hukum pidana, dalam KUHP disebutkan jenis-jenis kejahatan yang diatur dalam Pasal 10 KUHP. Hukuman dibagi menjadi dua kategori, kejahatan utama dan hukuman tambahan. Hukuman utama termasuk hukuman mati, penjara, penjara dan denda. Sementara itu, termasuk sanksi lain, yaitu pencabutan hak tertentu, penyitaan barang tertentu, dan pengumuman putusan hakim. Penjarahan merupakan suatu tindak pidana yang tergolong dalam Pencurian berat atau pencurian yang memenuhi syarat. Pencurian yang memenuhi syarat ini mengacu pada pencurian yang dilakukan dengan cara tertentu atau dalam keadaan tertentu, sehingga lebih berat dari pencurian biasa. Memang di dalam Kitab Undang-Undang Hukum Pidana tidak diatur secara khusus mengenai penjarahan. Namun karena penjarahan termasuk ke dalam pencurian dengan pemberatan maka penjarahan diatur dalam pasal 363 Kitab Undang-Undang Hukum Pidana yang secara khusus menerangkan bahwa penjarahan diancam pidana paling lama 7 tahun.

\section{Pertimbangan Hakim Dalam Menjatuhkan Pidana Terhadap Pelaku Tindak Pidana Penjarahan}

Dalam menghukum terdakwa dalam kasus perampokan, hakim mempertimbangkan UU Pidana II dan UU No. 8 Tahun 1981 (tentang UU Acara Pidana) dan Pasal 363 (1) peraturan perundang-undangan yang berlaku. Tanggung jawab pidana asing dikenal dengan istilah Teori pertanggungjawaban pidana yang mengarah pada pemidanaan terpidana adalah untuk menentukan apakah terdakwa atau tersangka bertanggung jawab atas kejahatan yang telah terjadi.

Rumusan pengertian pertanggungjawaban pidana pertama kali dicantumkan dalam Pasal 27 RKUHP 1982/1983 mengatakan pertanggungjawaban pidana adalah diteruskannya celaan yang 
objektif ada pada tindakan berdasarkan hukum yang berlaku secara subjektif (Prakoso, 1987). Pembahasan pertanggungjawaban pidana tidak lepas dari pembahasan tindak pidana. Jika seseorang tidak melakukan kejahatan, tidak mungkin dimintai pertanggungjawaban. Penulis sering memaparkan unsur-unsur perilaku kriminal dan pertanggungjawaban pidana yang harus diwujudkan ketika melakukan tindak pidana. Kejahatan dan kejahatan adalah elemen inti dalam hukum pidana. Unsur acara pidana terletak pada bidang obyektif diikuti unsur yang bersifat ilegal, sedangkan unsur pertanggungjawaban pidana adalah unsur subyektif yang terdiri atas kemampuan bertanggung jawab dan adanya kesalahan (niat dan kelalaian). Asas "no error and no punishment" sering disebut sebagai inti hukum pidana, karena masalah pertanggungjawaban pidana mengikuti asas, yaitu adanya unsur bersalah dalam diri seseorang. Padahal, "Hukum Pidana" atau peraturan lain di luar "Hukum Pidana" tidak menjelaskan secara jelas arti kesalahan tersebut. Asas rasa bersalah ini telah diakui dan menjadi dasar pertimbangan hakim dalam melakukan tindak pidana terhadap tindak pidana. Ini berarti bahwa seseorang tidak dapat disalahkan atas suatu kejahatan, dan akibatnya, mereka tidak dapat dimintai pertanggungjawaban atas kejahatan tersebut. Kemampuan untuk bertanggung jawab menjadi alasan mengapa pelaku bertanggung jawab atas kejahatan tersebut. Sebaliknya, jika seseorang menjadi tidak mampu memikul tanggung jawab karena kondisi tertentu, maka ketidakmampuan memikul tanggung jawab menjadi alasan mengapa ia tidak memikul tanggung jawab pidana. Mengenai kemampuan untuk membuat orang memiliki tiga macam tanggung jawab atas tindak pidana yang dilakukannya, yaitu sebagai berikut:

1. Mampu mengetahui akan maksud yang sebenarnya itu dapat atau tidak dapat dari apa yang ia lakukan;

2. Mampu menyadari bahwa tindakannya itu dapat atau tidak dapat dibenarkan oleh masyarakat; dan

3. Mampu menentukan kehendak terhadap apa yang ingin ia lakukan. Kemampuan untuk bertanggung jawab dapat diartikan sebagai kondisi psikologis, dan upaya untuk menghukum dapat dibenarkan dari sudut pandang umum dan dari sudut pandang manusia. Jika jiwa seseorang sehat dan dapat mengetahui atau menyadari bahwa tindakannya ilegal, dia dapat dimintai pertanggungjawaban. Dia bisa menentukan keinginannya berdasarkan kesadaran ini.

Bagaimanapun, hukum harus ditegakkan untuk ketertiban umum. Bahkan undang-undang yang harus ditegakkan harus dikaitkan dengan ketertiban yang dapat menjamin keselamatan korban bencana. Misalnya, merampok narkoba, jika tidak ada pesanan, bahkan jika tidak memahami fungsi narkoba, akan memberikan hak kepada masyarakat untuk menumpuk narkoba dengan leluasa. Di sisi lain, karena obat tidak tersedia, orang lain yang membutuhkannya menjadi tidak dapat disembuhkan. Ibarat makanan, orang yang menumpuk makanan akan kenyang sedangkan yang lain bisa mati kelaparan.

Hukum pidana juga membuat pembedaan lain berdasarkan keyakinan atas perbuatan dan keyakinan pembuatnya. Penghapusan tindak pidana dapat dikaitkan dengan perbuatan atau penciptanya, sehingga alasan penghapusan tindak pidana dibedakan menjadi beberapa jenis, yaitu:

1. Alasan pembenar

Alasan pembenar atau rechtsvaardigingsgrond ini yaitu alasan menghapuskan sifat melawan hukum sehingga apa yang dilakukan terdakwa menjadi perbuatan yang patut dan benar. Hal ini untuk menghilangkan sifat hukum dan perilaku yang melanggar KUHP. Karena sifat ilegalnya dihilangkan, dapat dibuktikan bahwa perilaku ilegal aslinya adalah wajar.

2. Alasan pemaaf

Alasan pemaaf atau schulduitsluitingsgrond Ini melibatkan tanggung jawab seseorang atau tanggung jawab pidana atas tindakan kriminal yang dilakukan. Alasan adalah alasan untuk menghilangkan rasa bersalah terdakwa. Perilaku terdakwa masih ilegal. Oleh karena itu, ini tetap merupakan tindak pidana, namun ia tidak dihukum karena tidak melakukan kesalahan.

3. Alasan penghapus tuntutan

Alasan penghapus Masalahnya adalah bahwa penuntutan ada di sini tanpa pembenaran atau alasan apa pun. Oleh karena itu, tidak ada pertimbangan yang diberikan untuk sifat tindakan atau sifat orang yang melakukan tindakan tersebut. Kepentingan umum dipertimbangkan di sini. Kecuali ada alasan yang masuk akal untuk menghilangkan sifat ilegal dari tindakan tersebut, dan tidak ada alasan untuk menghilangkan tanggung jawab pidana pelanggar dan dengan demikian menghilangkan alasan untuk menghukum pelaku, ada alasan lain sebelum 
alasan pidana. Jika alasan ini diterima, maka jaksa tidak akan bisa mengadili. Alasan-alasan inilah yang menjadi alasan lokal diberlakukannya KUHP. Ini menjawab pertanyaan apakah perilaku tersangka termasuk dalam ruang lingkup Hukum Pidana. Kita harus mengingat Pasal 2 sampai 8 KUHP. Jika tindakan tersebut diterapkan dalam klausul di atas, tidak ada penuntutan yang dapat (Pawennei \& Tomalili, 2015).

Orang yang dituduh melakukan tindak pidana dapat memberikan pembelaan atau menghilangkan alasan terjadinya tindak pidana tersebut. Alasan dapat bersifat umum (pembelaan umum) atau alasan khusus (pembelaan khusus). Alasan tersebut hanya dapat dikemukakan untuk kejahatan atau tindak pidana tertentu (Narwawi, 1994). Yang termasuk alasan penghapusan pidana yang bersifat umum yaitu paksaan, keracunan atau mabuk-mabukan, gerakan reflex, kegilaan atau ketidakwarasan, anak di bawah umur, persetujuan korban. Sedangkan yang terdiri dari alasan penghapus pidana bersifat khusus yaitu kehamilan (jika berlanjut) membahayakan nyawa ibu dan anak yang lahir dapat mengalami cacat fisik atau mental yang parah.

Dalam judul buku pertama KUHP terdapat beberapa muatan yang menghapus, mengurangi atau memperburuk tindak pidana yaitu ketidakmampuan memikul tanggung jawab, di bawah 16 tahun, terlalu tua, pembelaan paksa, peraturan hukum, perintah dinas dan berbagai posisi.

\section{SIMPULAN DAN SARAN \\ 1. Simpulan}

Sanksi pidana bagi pelaku tindak pidana yang melakukan penjarahan diatur dalam KUHP Pasal 363 ayat (1) ke-2 yang menyatakan bahwasannya bagi seseorang yang melakukan pencurian pada saat terjadi kebakaran, letusan, banjir, gempa bumi, gempa laut, gunung meletus, kapal karam, kapal terdampar, kecelakaan kereta api, huru-hara, pemberontakan atau bahaya perang maka akan dikenakan sanksi pidana berupa pidana penjara paling lama 7 (tujuh) tahun. Pertimbangan hakim dalam menjatuhkan pidana terhadap pelaku tindak pidana penjarahan yaitu seseorang yang melakukan pencurian pada saat bencana kebakaran, letusan, banjir, gempa bumi, gempa laut, gunung meletus, kapal karam, kapal terdampar, kecelakaan kereta api, huru-hara, pemberontakan atau bahaya perang dikategorikan sebagai pencurian dengan pemberatan atau pencurian yang dikualifikasikan. Hal yang memberatkan yaitu pencurian tersebut dilakukan pada saat terjadi bencana yang padahal seharusnya masyarakat saling bahu membahu untuk menolong para korban bencana.

\section{Saran}

Hendaknyalah pemerintah khususnya aparat penegak hukum dapat bersikap tegas untuk menegakkan keadilan bagi para pelaku tindak pidana penjarahan. Hukum yang ditegakkan harus menawarkan apresiasi untuk mendorong warga agar tidak mengambil segala sesuatu yang bukan miliknya dan tidak mengambil paksa milik orang tanpa seizin pemiliknya. Selain dalam menegakkan hukum, pengawasan yang dilakukan pemerintah khususnya aparat keamanan harus diperketat dan dipertegas sehingga tidak ada celah yang dapat dilakukan masyarakat untuk melakukan penjarahan. Tentu jika pemerintah bisa bersikap tegas maka akan meminimalisir tingkat kriminal di Indonesia. Seyogyanya kita sebagai rakyat Indonesia yang tentu memegang teguh serta mengamalkan sila-sila dalam Pancasila maka sudah seharusnya saling membantu jika saudara kita menjadi korban bencana. Memanfaatkan keadaan apalagi ketika bencana hanya untuk kepentingan pribadi tentu bukan solusi dalam keadaan darurat seperti bencana. Jadi, jika terjadi bencana maka tindakan yang harus kita lakukan adalah saling membantu untuk menguatkan dan menyelamatkan satu sama lain. Kesadaran masyarakat Indonesia untuk tidak melakukan segala sesuatu yang sifatnya melawan hukum merupakan poin penting dalam warisan budaya produk hukum. Adapun bagi pelaku, Seperti yang kita ketahui bersama bahwasannya Indonesia adalah negara hukum maka dari itu sudah seharusnya kita sebagai warga negara mentaati aturan yang berlaku dan tidak melakukan perbuatan yang melawan hukum. Bagi warga negara Indonesia yang pernah menjadi terdakwa tindak pidana penjarahan diharapkan untuk tidak mengulangi kesalahan yang sama agar kita semua dapat hidup dengan tentram dan tidak ada lagi perbuatan melawan hukum yang dapat meresahkan masyarakat.

\section{DAFTAR PUSTAKA}

Faucon, C. E. (2010). The Suspension Theory: Hurricane Katrina Looting, Property Rights, and Personhood. Louisiana Law Review, 70(4), 1303-1338. 
Hartono, S. (1994). Penelitian hukum di Indonesia pada abad ke-20. Alumni, Bandung.

Hasan. (2021). Analisis Kriminologi Penjarahan Pada Saat Terjadi Bencana Alam (Studi Kasus Wilayah Hukum Polres Palu). Tadulako Master Law Journal, 5(2), 214-227.

Nainggolan, P. P. (2013). Kapitalisme Internasional dan Fenomena Penjarahan Lahan di Indonesia. Jurnal Politica, 4(2), 225-262.

Narwawi, B. (1994). Perbandingan Hukum Pidana. Raja Grafindo Persada, Jakarta.

Pawennei, M., \& Tomalili, dan R. (2015). Hukum Pidana. Mitra Wacana Media, Jakarta.

Prakoso, D. (1987). Pembaruan Hukum Pidana di Indonesia. Liberty, Yogyakarta.

Prasetyo, T. (2010). Hukum Pidana. Raja Grafindo Persada, Jakarta.

Sidiq, H. N. (2019). Tindakan Kepolisian dalam Menyelesaikan Masalah Penjarahan/Pencurian disaat Terjadi Suatu Bencana Alam. Journal of Law, 1(1), 1-26.

Soesilo, R. (1972). Pokok-Pokok Hukum Pidana Peraturan Umum dan Delik-Delik Khusus. PT. Karya Nusantara, Bandung.

Susan. (2019). Tinjauan Yuridis Terhadap Tindak Pidana Penjarahan dan Pencurian di Bidang Perkebunan dalam Perspektif Penegakan Hukum. Wasaka Hukum, 7(2), 282-298. 